\title{
Integrated Simulation of Spillway and Diversion Structure in Flood Risk Assessment of Upper Solo River
}

\author{
Saraswati Renaningsih \\ Agency of Public Housing and Settlement Area, Bangka-Belitung Province, Pangkal Pinang, INDONESIA \\ ayas_27@yahoo.com
}

\begin{abstract}
Wonogiri Reservoir is a multi-purpose hydraulic structure that is used for water supply service and flood control in the watershed area of Upper Solo River. Inflow of the Wonogiri Reservoir comes from 10 rivers in the watershed's catchment area. As for the purpose of reservoir's sediment controller, a new spillway is constructed; and also closure dike is being built, which influenced the change on reservoir storage characteristic, and then means that a new reservoir operation guideline is necessary. Therefore, study on flood routing on the watershed of Upper Solo River at the new condition of the reservoir operation is needed. The analysis was conducted to acquire detailed information on flood characteristics of Wonogiri Reservoir and Upper Solo River started from the downstream of the reservoir until the downstream control point in the Jurug Water Level Recorder including the flood discharge and the maximum water level. The analysis procedure was performed by four components, which are flood forecasting, reservoir flood routing, rainfall-runoff lateral inflow, and hydraulic channel routing. The analysis result was integrated into a software package which was arranged by using the Microsoft Visual Studio Express 2012, Microsoft Access, and HEC-RAS. With the support of the software, it was expected that the decision making in the spillway operational is more quickly and more accurate (rapid assessment) in order to improve the flood control performance in the area of Upper Solo River.
\end{abstract}

Keywords: Wonogiri Reservoir; characteristic change; reservoir storage; reservoir operational guidelines; flood routing

\section{INTRODUCTION}

Solo River (Bengawan Solo) is the longest river in Java Island, with the main course is up to $\pm 600 \mathrm{~km}$, as seen in Figure 1. Flood disaster occurs almost every year, especially at rainy season. The government built Wonogiri Reservoir as one of the efforts for flood control in Solo River, particularly the upstream part.

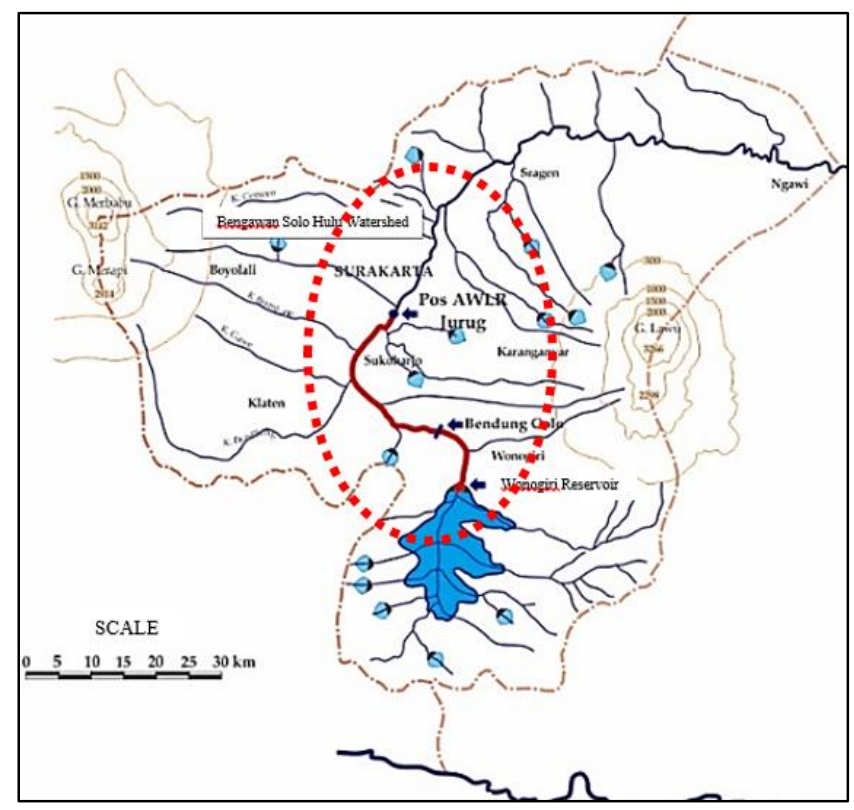

Figure 1. Map on research area.
Wonogiri Reservoir as the multi-purpose reservoir has functions for flood control, irrigation, and hydropower. The capacity of Wonogiri Reservoir is decreasing because of the sedimentation problem, which then leads to the decreasing of the reservoir function. As a reservoir sedimentation controller, a new spillway is built, and a closure dike is also being built, which influenced the change on reservoir's storage characteristic, and then means that a new reservoir operation guideline is necessary.

Wijaya (2014) has developed software in form of hydrology-hydraulic model for flood routing simulation in Solo River and reservoir up to the Jurug AWLR (Automatic Water Level Recorder) Station. Further development of the software is necessary, particularly on the component of flood flow from the Wonogiri Reservoir outlet up to the Jurug AWLR Station by hydraulics, in order to discover the flood characteristic at a certain control point that is located in the reservoir downstream.

The purposes of this research are to conduct study on flood characteristic in Upper Solo River after closure dike and new spillway was built, by taking into account the lateral inflow weight of the tributary in the reservoir downstream and to conduct software development that was resulted from previous research (Wijaya, 2014), by 
hydraulic calculation of flood routing from Wonogiri Reservoir outlet up to the Jurug AWLR Station.

\section{RESEARCH LOCATION}

\subsection{Wonogiri Reservoir}

The catchment area of Wonogiri Reservoir has 10 watersheds with total area of $1,343 \mathrm{~km}^{2}$ (Oktavia, 2013). The catchment area of Wonogiri Reservoir is illustrated in Figure 2, while detail of each area is listed in Table 1.

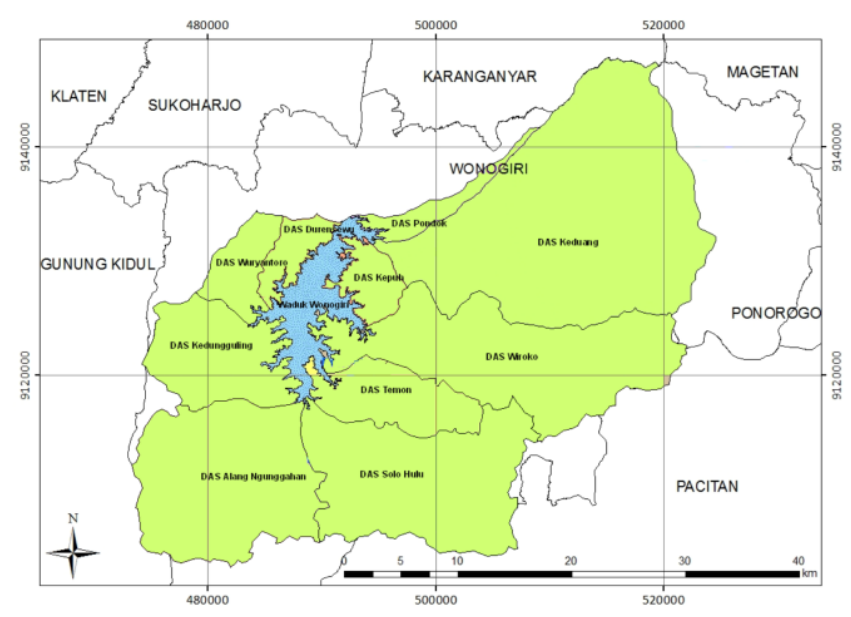

Figure 2. Catchment area of Wonogiri Reservoir.

Table 1. Watershed area of Wonogiri Reservoir

\begin{tabular}{|c|c|c|c|}
\hline No & Watershed Name & Area $\left(\mathrm{km}^{2}\right)$ & $\begin{array}{l}\text { Percentage } \\
(\%)\end{array}$ \\
\hline 1 & Alang Ngunggahan & 193.02 & 15.05 \\
\hline 2 & Durensewu & 26.15 & 2.04 \\
\hline 3 & Keduang & 397.36 & 30.97 \\
\hline 4 & Kedungguling & 96.05 & 7.49 \\
\hline 5 & Kepuh & 29.86 & 2.33 \\
\hline 6 & Pondok & 24.17 & 1.88 \\
\hline 7 & Solo Hulu & 193.62 & 15.09 \\
\hline 8 & Temon & 68.08 & 5.31 \\
\hline 9 & Wiroko & 216.95 & 16.91 \\
\hline \multirow[t]{2}{*}{10} & Wuryantoro & 37.60 & 2.93 \\
\hline & Total & $1,282.86$ & 100.00 \\
\hline
\end{tabular}

To overcome the sedimentation problem in Wonogiri Reservoir, a new spillway has been built and at the moment, a closure dike is currently being constructed. With the closure dike, water storage in Wonogiri Reservoir is separated into 2 (two), which is main reservoir (MR) and sediment storage reservoir (SSR). The scheme of Wonogiri Reservoir water storage after construction of closure dike could be seen in Figure 3 (Nippon Koei Co. Ltd, 2007). The construction of closure dike and new spillway changed the operational pattern of the reservoir spillway (Gupitakingkin, 2014). The new guideline is shown in Table 2.

Table 2. New guideline on Wonogiri Reservoir spillway gate operation at flood period

\begin{tabular}{|c|c|c|}
\hline Maximum & Operational Pattern & \\
\hline $\begin{array}{l}\text { Flood } \\
\text { Discharge } \\
(\mathrm{m} 3 / \mathrm{s})\end{array}$ & New Spillway & $\begin{array}{l}\text { Old } \\
\text { Spillway }\end{array}$ \\
\hline $\begin{array}{l}4,400 \\
(Q 60)\end{array}$ & $\begin{array}{l}\text { If inflow }<400 \mathrm{~m}^{3} / \mathrm{s} \text { then } \\
\text { outflow }=\text { inflow } \\
\text { If inflow }>400 \mathrm{~m}^{3} / \mathrm{s} \text { then } \\
\text { outflow }=400 \mathrm{~m}^{3} / \mathrm{s} \\
\text { If TMA }>\text { Elevation } 138.20 \mathrm{~m} \\
\text { then spillway gate completely } \\
\text { opened a }=5.6 \mathrm{~m}\end{array}$ & $\begin{array}{l}\text { Not } \\
\text { operated }\end{array}$ \\
\hline $\begin{array}{l}6,500 \\
(Q 500)\end{array}$ & $\begin{array}{l}\text { If inflow }<800 \mathrm{~m}^{3} / \mathrm{s} \text { then } \\
\text { outflow }=\text { inflow } \\
\text { If inflow }>800 \mathrm{~m}^{3} / \mathrm{s} \text { then } \\
\text { outflow }=800 \mathrm{~m}^{3} / \mathrm{s} \\
\text { If TMA } \geq \text { Elevation } 138.20 \\
\mathrm{~m} \text { then gate completely } \\
\text { opened a }=5.6 \mathrm{~m}\end{array}$ & $\begin{array}{l}\text { Not } \\
\text { operated }\end{array}$ \\
\hline $\begin{array}{l}9,600 \\
(Q 5,500)\end{array}$ & $\begin{array}{l}\text { If inflow }<800 \mathrm{~m}^{3} / \mathrm{s} \text { then } \\
\text { outflow }=\text { inflow } \\
\text { If inflow }>800 \mathrm{~m}^{3} / \mathrm{s} \text { then } \\
\text { outflow }=800 \mathrm{~m}^{3} / \mathrm{s} \\
\text { If TMA } \geq \text { Elevation } 138.20 \\
\mathrm{~m} \text { then gate completely } \\
\text { opened } \mathrm{a}=5.6 \mathrm{~m}\end{array}$ & $\begin{array}{l}\text { Operated } \\
\text { according } \\
\text { spillway } \\
\text { gate } \\
\text { operational } \\
\text { manual } \\
\text { table }\end{array}$ \\
\hline
\end{tabular}

\subsection{Upper Solo River Watershed}

In Upper Solo River watershed Wonogiri Reservoir Colo Weir, there are 12 sub-watersheds with total area of $183 \mathrm{~km}^{2}$ (Amalia, 2014). On the watershed of Upper Solo River Colo Weir up to the Jurug AWLR Station, there are 14 sub-watersheds with total area of 1,738 $\mathrm{km}^{2}$ (Gunawan, 2009), as shown in Figure 4.

\subsection{Colo Weir and Jurug AWLR Station}

Colo Weir is located in Pengkol Village, Nguter Subdistrict, Sukoharjo Regency, Central Java Province. This construction is aimed to regulate the water level of Solo River, so it could be used for irrigation purpose. The Jurug AWLR Station is located in Jurug Village, Pucang Sawit Sub-district, Surakarta City. 


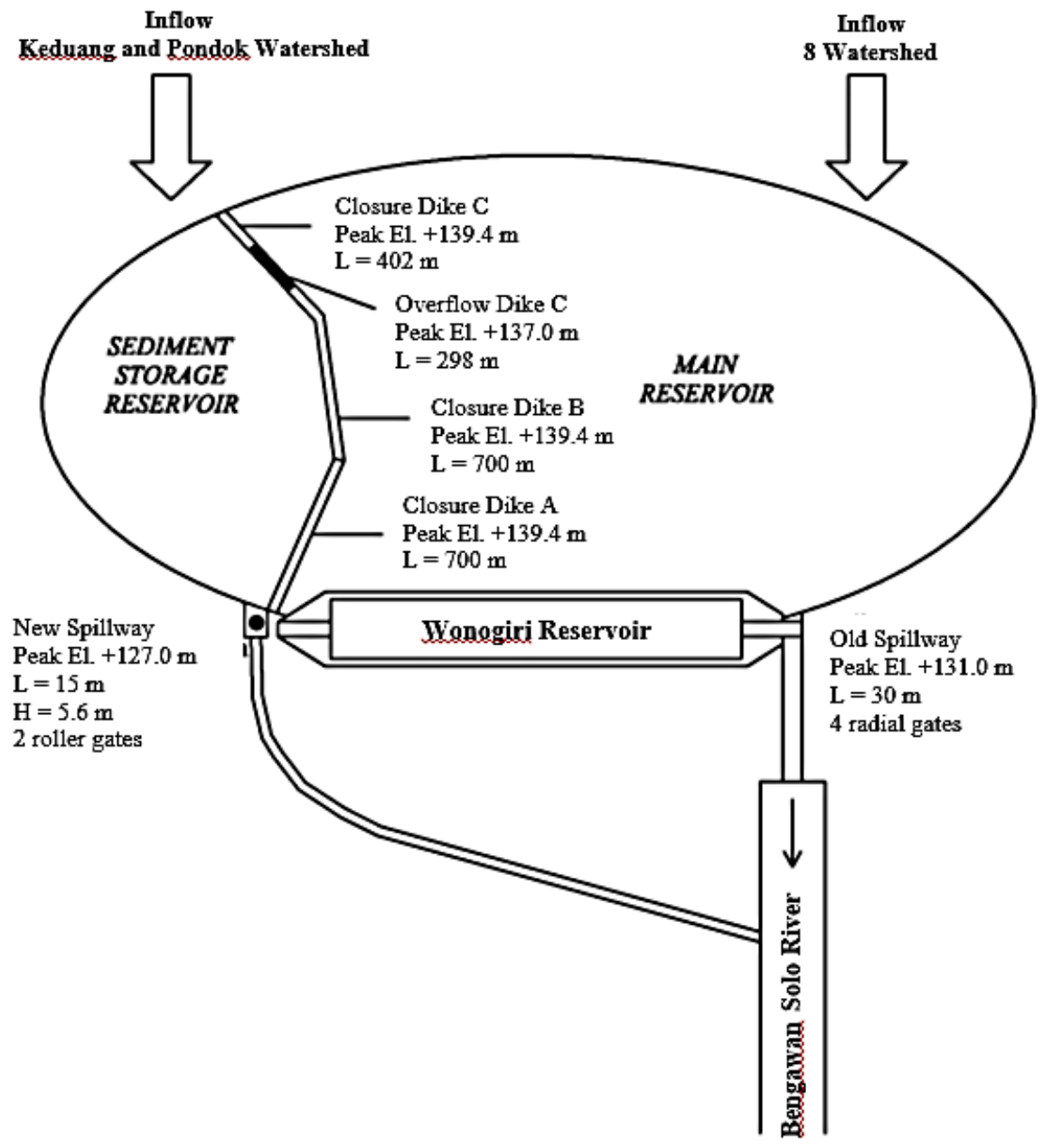

Figure 3. Scheme for the reservoir water storage after the construction of closure dike.

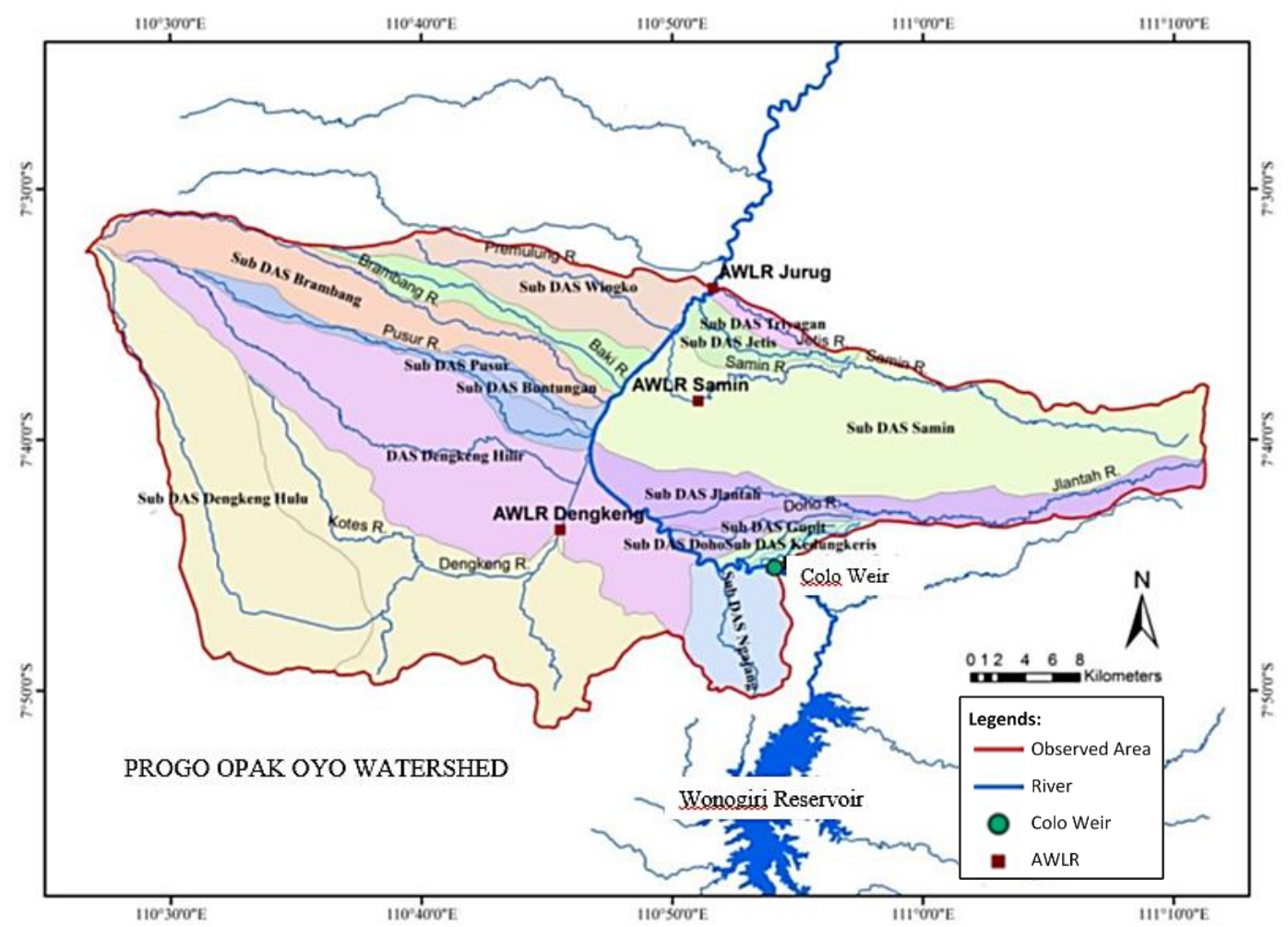

Figure 4. Area of upper Solo River watershed Colo Weir - Jurug AWLR station. 


\section{PREVIOUS RESEARCH ON SOLO RIVER}

Amalia (2014) conducted research about calculation on simulation of lateral inflow contribution to flood discharge in Colo Weir. The conclusion of this research was that the Wonogiri Reservoir operational in flood period at old condition (before construction of closure dike and new spillway) is safer compared to at the new condition.

Hanova (2014) developed visual basic-based software that modeled rain transformation into flow, for the purpose of tributary flood hydrograph and flood routing in Solo River. The arrangement of the software program was based on procedure of calculation and hydrology analysis formulations that Amalia (2014) generated.

Amalia (2014) conducted research on flood characteristic in Solo River Colo Weir - Surakarta City. The result of this research showed that the flood characteristic is affected by lateral inflow from the watershed's tributaries; with the biggest contribution comes from Dengkeng River.

Wijaya (2014) developed software to support flood routing in Upper Solo River watershed, in the form of hydrology-hydraulic model. This software was developed by integrated hydrology-hydraulic monitoring system, which consisted of 3 components: flood forecasting, reservoir flood routing and hydrologic channel routing.

\section{THEORETICAL BASIS}

\subsection{Water Balance in Reservoir}

The water balance in the reservoir meets the following equation.

$$
\frac{\Delta S}{\Delta t}=\sum_{i=1}^{i} \frac{I_{i}}{\Delta t}-\sum_{j=1}^{j} \frac{o_{j}}{\Delta t}
$$

in which $\Delta S$ denotes storage change in reservoir $\left(\mathrm{m}^{3}\right), I_{i}$ is inflow discharge at time $i$ to reservoir $\left(\mathrm{m}^{3} / \mathrm{s}\right), O_{j}$ is outflow discharge from reservoir $\left(\mathrm{m}^{3} / \mathrm{s}\right)$ at time $j, \Delta_{t}$ is interval of routing time (s).

\subsection{Flood Routing in Reservoir}

Flood routing in reservoir used the level pool routing method, with following equations.

$$
I-O=\frac{d S}{d t}
$$

whereas $d S$ is storage change in reservoir $\left(\mathrm{m}^{3}\right)$ and $d t$ is interval of routing time (hour).

Equation (1) showed that storage change between time intervals $d t$ is the same with inflow minus the outflow. If the interval of routing time is $\Delta t$, the Equation (1) could be written as:

$$
\frac{I_{1}+I_{2}}{2}-\frac{O_{1}+O_{2}}{2}=\frac{S_{1}+S_{2}}{\Delta_{t}}
$$

where $S_{1}, S_{2}$ are storage at the first and second time, respectively.

Equation (3) could be written in form of:

$$
\frac{2 S_{2}}{\Delta_{t}}-O_{2}=I_{1}+I_{2}+\frac{2 S_{1}}{\Delta_{t}}-O_{1}
$$

4.3 Storage through Overflow Dike and Closure Dike Common equation used in hydraulic of broad-crested spillway is as follows:

$$
Q=C L H^{\frac{3}{2}}
$$

whereas $Q$ id storage that goes through broad-crested spillway $\left(\mathrm{m}^{3} / \mathrm{s}\right), L$ is length of broad-crested spillway perpendicular to the direction of flow (m), $H$ is depth of water surface above the crest of broad-crested spillway at downstream (m).

Front-view sketch of the overflow and closure dike is shown in Figure 5. (Nippon Koei Co. Ltd, 2007).

Note:

Elevation of overflow dike $\quad=+137 \mathrm{~m}$

Elevation of closure dike peak $\quad=+139.4 \mathrm{~m}$

Bottom width of overflow dike $(B) \quad=250 \mathrm{~m}$

Top width of overflow dike $(T) \quad=250 \mathrm{~m}$

Normal depth $(N D) \quad=2.4 \mathrm{~m}$

Total length $(\mathrm{CW}) \quad=2,100 \mathrm{~m}$

Slope angle of overflow dike $\quad=84.29^{\circ}$

Discharge coefficient $\left(C_{d}\right) \quad=1.69$

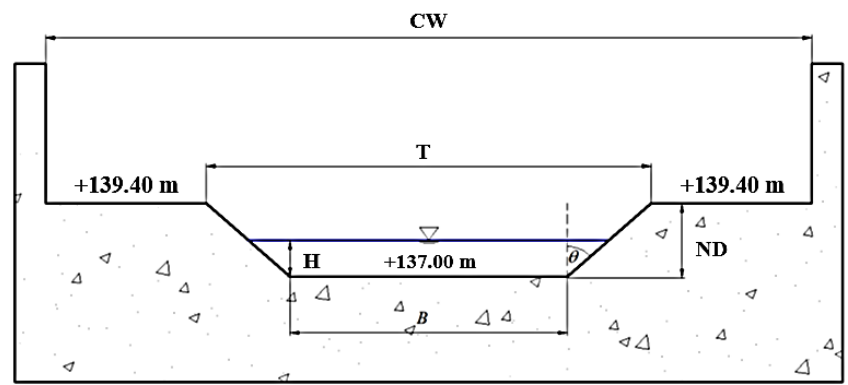

Figure 5. Front-view sketch of the overflow and closure dike. 


\subsection{Storage through Overflow Dike on Overflow Dike}

Equation that enters the Main Reservoir $(M R)$ on the condition of:

Zero Flow (no flow between discharge), $Q=0$

Free Flow

$$
Q=C_{d}\left(B H^{1.5}+\tan \theta H^{2.5}\right)
$$

Submerged Flow

$$
Q=C_{d}\left[B H^{1.5}+\tan \theta H^{2.5}\right]\left(1-\left(\frac{h}{H}\right)^{1.5}\right)^{0.385}
$$

in which $h$ is water height above the overflow dike on $M R$ and $S S R$ is Sediment Storage Reservoir.

Equation that enters the $S S R$ on the condition of:

Zero Flow (no flow between discharge), $Q=0$

Free Flow

$$
Q=C_{d}\left(B h^{1.5}+\tan \theta h^{2.5}\right)
$$

Submerged Flow

$$
Q=C_{d}\left[B h^{1.5}+\tan \theta h^{2.5}\right]\left(1-\left(\frac{H}{h}\right)^{1.5}\right)^{0.385}
$$

\subsection{Flood Routing in River Course}

Flood routing in the river course was conducted with HEC-RAS 4.1.0 software. The basic formula/calculation of flow in unsteady flow is as follows.

Continuity equation (mass conversion principal)

$$
\frac{\partial A}{\partial t}+\frac{\partial Q}{\partial x}-q_{t}=0
$$

Momentum equation (momentum conversion principal)

$$
\frac{\partial Q}{\partial t}+\frac{\partial Q V}{\partial x}+q_{A}\left(\frac{\partial z}{\partial x}+S_{f}\right)=0
$$

in which $A$ means total area of flow section (total of flow section area in main channel and overbank channel) $\left(\mathrm{m}^{2}\right), q t$ is lateral discharge per length unit $\left(\mathrm{m}^{3} / \mathrm{s}\right), v$ is flow velocity $(\mathrm{m} / \mathrm{s}), g$ is gravitational acceleration $\left(\mathrm{m} / \mathrm{s}^{2}\right), x$ is distance, measured in the direction of flow (m), $z$ is water level $(\mathrm{m})$, and $S_{f}$ is energy gradient (friction slope) which is defined as follows:

$$
S_{f}=\frac{n^{2}|Q| Q}{A^{2} \mid R^{2}}
$$

whereas $n$ denotes Manning coefficient roughness and $R$ is hydraulic radius (m).

\section{RESEARCH METHOD}

\subsection{Concept of Model Development}

The main components in developing the hydrologyhydraulic model in flood routing of Upper Solo River watershed are the flood forecasting, reservoir flood routing, rainfall-runoff lateral inflow and hydraulic flood routing. Scheme of the model can be seen in Figure 6.

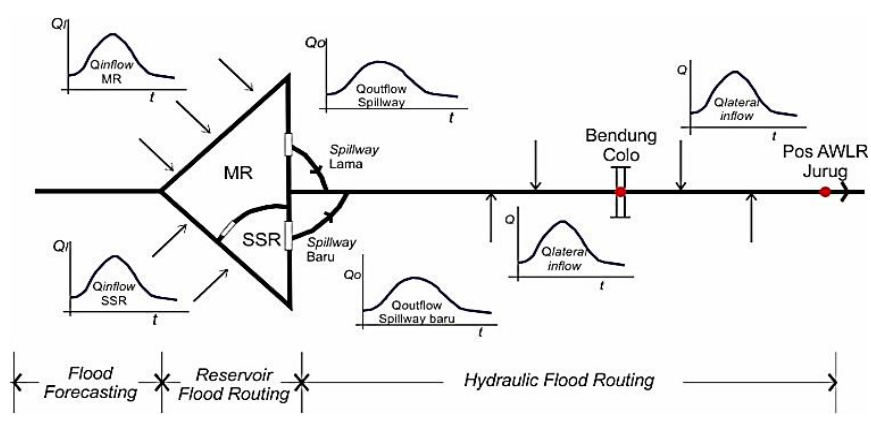

Figure 6. Scheme on software development.

\subsection{Software Arrangement}

The software was arranged by using Microsoft Visual Studio Express 2012 software. The main structure of the software was arranged with 4 main components, which are flood forecasting, reservoir flood routing, rainfall-runoff lateral inflow, and hydraulic flood routing. The simulation stages are presented as shown in Figure 7. 


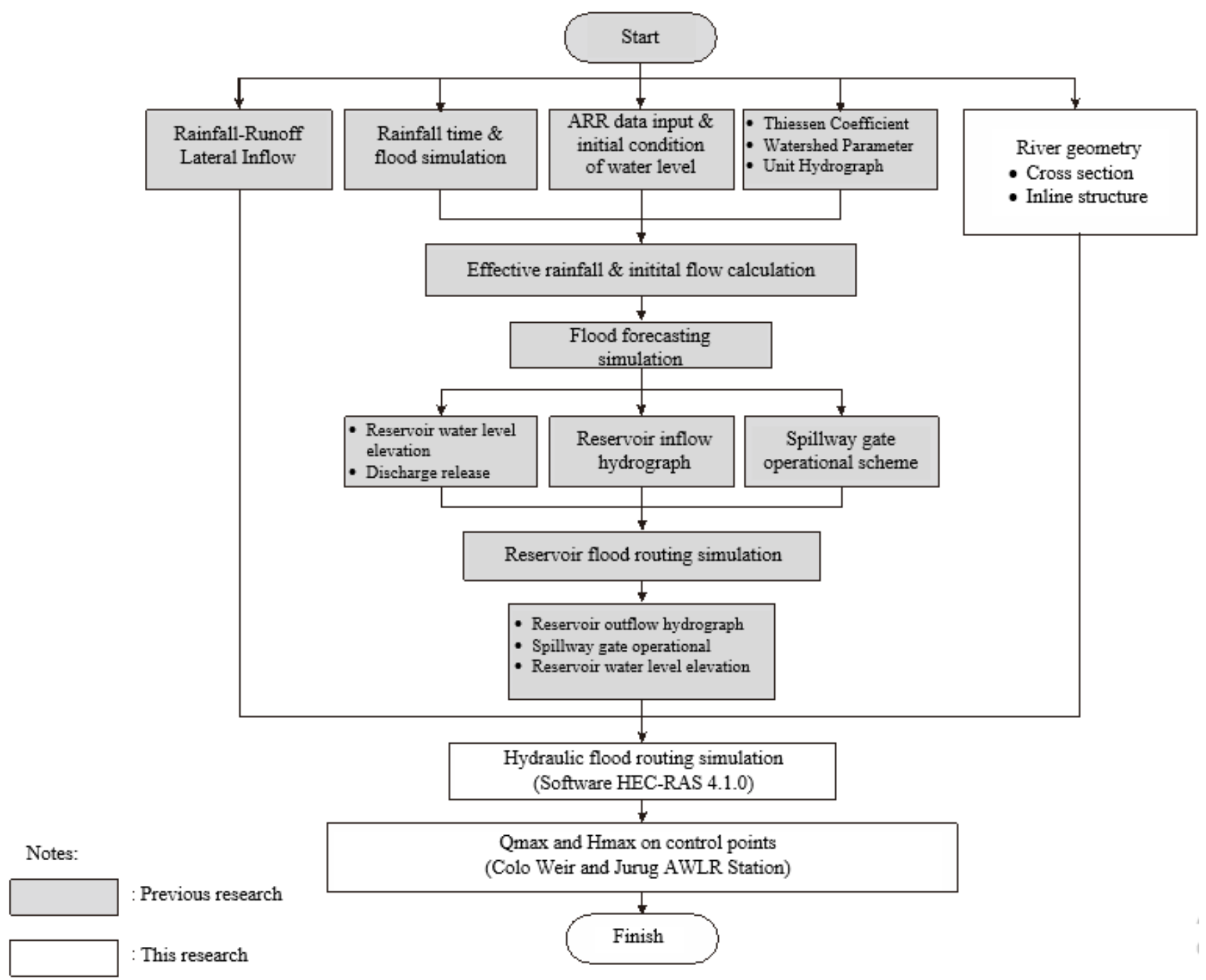

Figure 7. Chart of software main structure.

\subsection{Database Arrangement of Software}

Database of flood routing software for Upper Solo River was arranged with the Microsoft Access software. The input and output of each simulation ais presented in Table 3.

Table 3. Input and output of simulation data in software

\begin{tabular}{lll}
\hline Component & Input & Output \\
\hline $\begin{array}{l}\text { Flood } \\
\text { Forecasting }\end{array}$ & Real-time rainfall data, Thiessen coefficient, Initial Flow, and & Flood hydrograph of Wonogiri \\
Reservoir Flood & hydrograph of watershed outlet unit & Reservoir inflow \\
Routing & Flood hydrograph of Wonogiri Reservoir inflow, reservoir & Spillway gate opening height, outflow \\
& pattern of Wonogiri Reservoir at flood period and discharge & Reservoir and Sediment Storage \\
& release & Reservoir) \\
Rainfall-Runoff & Real-time rainfall data, Thiessen coefficient, Initial Flow, and & Lateral flood hydrograph Wonogiri \\
Lateral Inflow & hydrograph of watershed outlet unit & Reservoir -Jurug AWLR Station inflow \\
Hydraulic Flood & Outflow discharge of Wonogiri Reservoir (Main Reservoir and & Discharge, water level gauge, velocity \\
Routing & Sediment Storage Reservoir), lateral flood hydrograph Wonogiri & on control point (Colo Weir Jurug \\
& Reservoir-Jurug AWLR Station and river geometry & AWLR Station) \\
\hline
\end{tabular}




\section{a) Hydrology Station}

The hydrology data that was used for data input was based on the result of hourly monitoring which was recorded on 10 Automatic Rainfall Recorder Stations (ARR) and 6 AWLR in the watershed of Upper Solo River, which was managed by Perum Jasa Tirta I.

\section{b) Curve Number Value}

Curve Number $(C N)$ value that was used as a constant in this simulation program, which was based on the previous research result. $C N$ values of Wonogiri watershed are shown in Table 4, while $C N$ values in Upper Solo River watershed are shown in Table 5 which was based on research of Amalia (2014).

Table 4. CN value in Wonogiri Reservoir catchment area (Oktavia, 2013)

\begin{tabular}{llll}
\hline No & Watershed & Composite $C N$ & $C N($ AMC III) \\
\hline 1 & Pondok & 63.56 & 80.05 \\
2 & Keduang & 71.62 & 85.31 \\
3 & Kepuh & 73.46 & 86.42 \\
4 & Wiroko & 81.64 & 91.09 \\
5 & Temon & 83.06 & 91.85 \\
6 & Solo Hulu & 82.91 & 91.78 \\
7 & Alang & 83.29 & 91.98 \\
& Ngunggahan & & \\
8 & Kedungguling & 84.68 & 92.71 \\
9 & Wuryantoro & 80.01 & 90.20 \\
10 & Durensewu & 75.12 & 87.41 \\
\hline
\end{tabular}

Table 5. $C N$ value in Upper Solo River Watershed, Colo Weir- Jurug AWLR Station (Amalia, 2014)

\begin{tabular}{llll}
\hline No. & Watershed & Composite $C N$ & $C N(A M C$ III $)$ \\
\hline 1 & Kedungkeris & 92.26 & 83.82 \\
2 & Gupit & 92.38 & 84.06 \\
3 & Ngajang & 93.90 & 87.00 \\
4 & Doho & 91.66 & 82.69 \\
5 & Jlantah & 88.85 & 77.60 \\
6 & Dengkeng Hulu & 82.67 & 72.57 \\
7 & Dengkeng Hilir & 85.87 & 72.54 \\
8 & Pusur & 82.83 & 67.72 \\
9 & Buntungan & 81.37 & 65.51 \\
10 & Brambang & 83.40 & 68.59 \\
11 & Kembangan & 82.66 & 67.45 \\
12 & Samin & 87.68 & 75.57 \\
13 & Wingko & 84.90 & 70.97 \\
14 & Jetis & 89.31 & 78.42 \\
15 & Triyagan & 88.10 & 76.30 \\
\hline
\end{tabular}

\section{c) Rating Curve}

Estimation calculation for initial flow used the water depth that was measured in 6 AWLR which was located in Upper Solo River watershed, with the rating curve that was available in each AWLR.

\section{d) Unit Hydrograph}

The unit hydrograph that was used as database on the watershed at Wonogiri Reservoir catchment area was based on research of Gupitakingking (2014), which was an update from the unit hydrograph on the research of Oktavia (2013). For the unit hydrograph in watershed of Upper Solo River, Wonogiri Reservoir until Colo Weir was based on research of Hanova (2014); whereas for unit hydrograph Colo Weir until Jurug AWLR Station was based from research of Amalia (2014).

\subsection{Flood Routing Simulation}

Simulation of reservoir flood routing was conducted to find the characteristic of Wonogiri Reservoir at flood at return period of 60 years, 500 years, and PMF. The flood characteristic in Upper Solo River Wonogiri Reservoir until Jurug AWLR Station was acquired by validity test on result of software simulation with the hydrology-hydraulic monitoring data that was present in the Solo River for certain flood condition.

\section{RESULT AND DISCUSSION}

\subsection{Result of Software Development}

The data input menu consisted of four tabs, which are time, real-time monitoring, Thiessen coefficient, and loss parameter. To find out the flood characteristic in Upper Solo River Wonogiri Reservoir until Jurug AWLR Station (see Figure 4), the software simulation used data input of real-time rainfall monitoring on January $25^{\text {th }} 2014$ (Table 7). This data was chosen because rain occurred for 12 hours, from 13:00 up to 24:00; therefore, at that time the Wonogiri Reservoir spillway released outflow discharge of $100 \mathrm{~m}^{3} / \mathrm{s}$ and increased into $140 \mathrm{~m}^{3} / \mathrm{s}$, in which this condition lasted for 73 hours.

Table 6. Data of hypothetical water level on AWLR station

\begin{tabular}{llllll}
\hline \multicolumn{7}{c}{ Water Depth $(\mathrm{m})$} \\
\hline Keduang & Wiroko & Temon & $\begin{array}{l}\text { Solo } \\
\text { Hulu }\end{array}$ & Walikan & Dengkeng \\
\hline 1.76 & 1.52 & 1.36 & 1.21 & 1.14 & 0.10 \\
\hline
\end{tabular}

The flood forecasting menu consists of 5 tabs which are unit hydrograph, effective rainfall, initial flow, reservoir inflow hydrograph, and total inflow hydrograph. From the simulation result, the reservoir 
inflow hydrograph can be obtained as shown in Figure 8 , which was the maximum discharge of $479 \mathrm{~m}^{3} / \mathrm{s}$ occurred at January $25^{\text {th }} 2014$ at 20:00, and was categorized as standard flood.

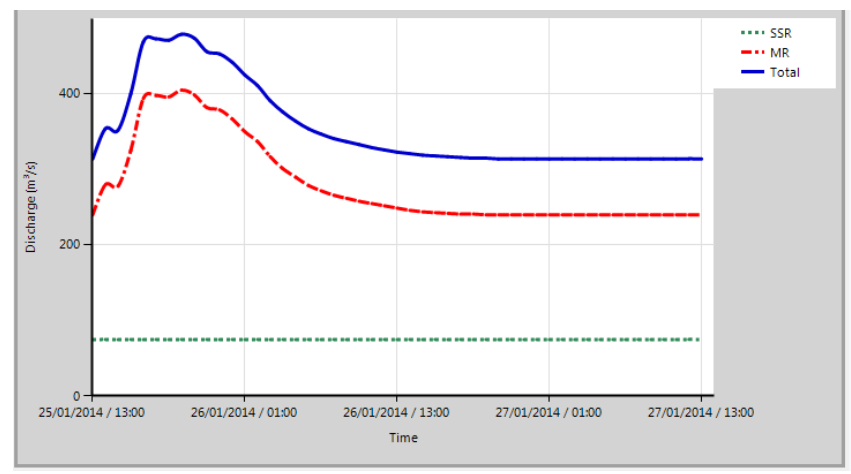

Figure 8. Flood forecasting simulation result.

On the menu reservoir flood routing, there are two tabs, which are tab initial condition of reservoir and outflow hydrograph. Result of reservoir flood routing simulation showed that the reservoir outflow discharge tends to be constant, which was $145 \mathrm{~m}^{3} / \mathrm{s}$ (Figure 9). This is in accordance with the function of the reservoir as flood controller, which is controlling outflow discharge through the spillway so that it is equal with the inflow discharge. From Figure 10, it could be seen that the inflow discharge on SSR tends to be constant, with the largest discharge is of $80 \mathrm{~m}^{3} / \mathrm{s}$.

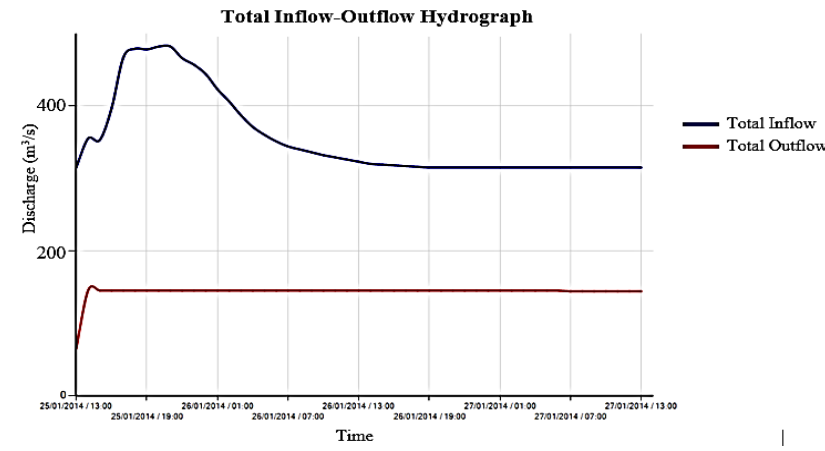

Figure 9. Reservoir outflow hydrograph

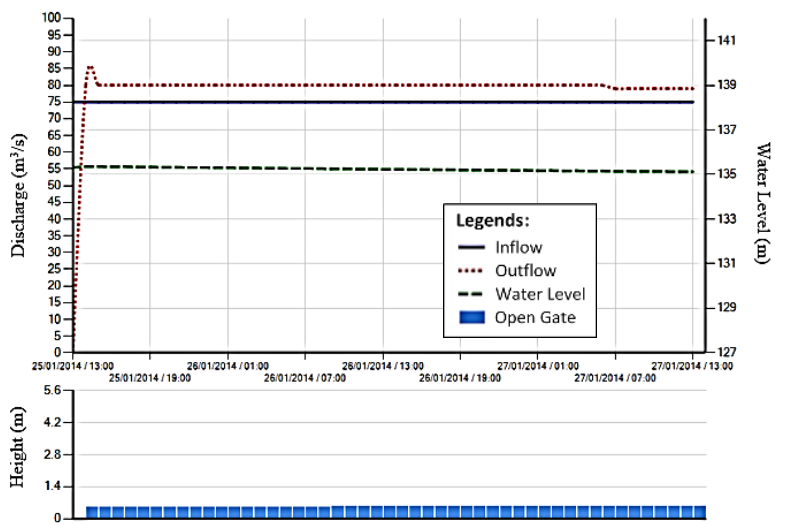

Figure 10. Outflow hydrograph of SSR resulted from reservoir flood routing simulation.

Table 7. Rainfall monitoring data on January $25^{\text {th }} 2014$

\begin{tabular}{|c|c|c|c|c|c|c|c|c|c|c|}
\hline \multirow[b]{2}{*}{ Hour } & \multicolumn{10}{|c|}{ Rainfall depth (mm) } \\
\hline & $\begin{array}{l}\text { Pracimantor } \\
\mathrm{o}\end{array}$ & Batuwarno & Tirtomoyo & Jatisrono & Wonogiri & $\begin{array}{l}\text { Col } \\
\text { o }\end{array}$ & Klaten & Matesih & Ngargoyoso & Boyolali \\
\hline 1 & 0.5 & 14 & 0 & 0 & 0 & 0 & 0 & 1 & 0 & 0 \\
\hline 2 & 0 & 0 & 0 & 0 & 0 & 0 & 0 & 4.5 & 0 & 0 \\
\hline 3 & 0.5 & 2 & 24.4 & 0 & 11.5 & 0 & 0.5 & 1.5 & 0 & 0 \\
\hline 4 & 0 & 0 & 9.8 & 0 & 3.5 & 0 & 0 & 1.5 & 0 & 0 \\
\hline 5 & 0.5 & 0 & 3.9 & 1 & 0 & 2.24 & 0 & 0 & 0 & 0 \\
\hline 6 & 0.5 & 0 & 1.4 & 0 & 0 & 1.12 & 0 & 0 & 0 & 0 \\
\hline 7 & 0.5 & 0 & 4.8 & 0 & 0 & 0.28 & 0 & 0 & 0 & 0 \\
\hline 8 & 0.5 & 0 & 2.2 & 0.5 & 0 & 0 & 0 & 0 & 0 & 0 \\
\hline 9 & 0.5 & 0 & 3.4 & 0 & 0 & 0 & 0 & 0 & 0 & 0 \\
\hline 10 & 0 & 0 & 3.1 & 0 & 0 & 0 & 0 & 0 & 0 & 0 \\
\hline 11 & 0 & 0 & 0 & 0 & 0 & 0 & 0 & 0 & 0.5 & 0 \\
\hline 12 & 0.5 & 0 & 0 & 0 & 0 & 0 & 0 & 0 & 0 & 0 \\
\hline
\end{tabular}

Table 8. Simulation final result summary

\begin{tabular}{|c|c|c|}
\hline Start Simulation Time & \multicolumn{2}{|c|}{ January, $25^{\text {th }} 2014-13: 00$} \\
\hline Maximum Water Level of SSR & $135.35 \mathrm{~m}$ & \\
\hline Maximum Water Level of MR & $135.86 \mathrm{~m}$ & \\
\hline Maximum Total Inflow of Wonogiri Reservoir & $479 \mathrm{~m}^{3} / \mathrm{s}$ & \\
\hline Maximum Total Outflow of Wonogiri Reservoir & $145 \mathrm{~m}^{3} / \mathrm{s}$ & \\
\hline Maximum Discharge of Colo Weir & $157.00 \mathrm{~m}^{3} / \mathrm{s}$ & at January $26^{\text {th }} 2014-15: 00$ \\
\hline Maximum Water Level of Colo Weir & $104.67 \mathrm{~m}$ & at January $26^{\text {th }} 2014-13: 00$ \\
\hline Maximum Discharge of AWLR Jurug & $249.00 \mathrm{~m}^{3} / \mathrm{s}$ & at January $27^{\text {th }} 2014-04: 00$ \\
\hline Maximum Water Level of AWLR Jurug & $80.70 \mathrm{~m}$ & at January $26^{\text {th }} 2014-18: 00$ \\
\hline
\end{tabular}


Table 9. New spillway gate operation and old spillway gate operation

\begin{tabular}{|c|c|c|c|c|}
\hline \multirow[t]{2}{*}{ Date - Time } & \multirow{2}{*}{$\begin{array}{l}\text { Time } \\
\text { (hour) }\end{array}$} & \multirow{2}{*}{$\begin{array}{l}\text { New Spillway Gate Operation } \\
\text { Gate Opening }(\mathrm{m})\end{array}$} & \multicolumn{2}{|c|}{ Old Spillway Gate Operation } \\
\hline & & & Gate1\&4 Opening $(\mathrm{m})$ & Gate $2 \& 3$ Opening $(\mathrm{m})$ \\
\hline $25 / 01 / 2014-13: 00$ & 0 & 0 & 0 & 0 \\
\hline $25 / 01 / 2014-14: 00$ & 1 & 0.56 & 0 & 0 \\
\hline $25 / 01 / 2014-15: 00$ & 2 & 0.56 & 0 & 0 \\
\hline $25 / 01 / 2014-16: 00$ & 3 & 0.56 & 0 & 0 \\
\hline $25 / 01 / 2014-17: 00$ & 4 & 0.56 & 0 & 0 \\
\hline 25/01/2014 - 18:00 & 5 & 0.56 & 0 & 0 \\
\hline $25 / 01 / 2014-19: 00$ & 6 & 0.56 & 0 & 0 \\
\hline $25 / 01 / 2014-20: 00$ & 7 & 0.56 & 0 & 0 \\
\hline $25 / 01 / 2014-21: 00$ & 8 & 0.56 & 0 & 0 \\
\hline $25 / 01 / 2014-22: 00$ & 9 & 0.56 & 0 & 0 \\
\hline $25 / 01 / 2014-23: 00$ & 10 & 0.56 & 0 & 0 \\
\hline $25 / 01 / 2014-00: 00$ & 11 & 0.56 & 0 & 0 \\
\hline 26/01/2014-01:00 & 12 & 0.56 & 0 & 0 \\
\hline $26 / 01 / 2014-02: 00$ & 13 & 0.56 & 0 & 0 \\
\hline $26 / 01 / 2014-03: 00$ & 14 & 0.56 & 0 & 0 \\
\hline 26/01/2014-04:00 & 15 & 0.56 & 0 & 0 \\
\hline 26/01/2014-05:00 & 16 & 0.56 & 0 & 0 \\
\hline $26 / 01 / 2014-06: 00$ & 17 & 0.56 & 0 & 0 \\
\hline $26 / 01 / 2014-07: 00$ & 18 & 0.56 & 0 & 0 \\
\hline 26/01/2014-08:00 & 19 & 0.56 & 0 & 0 \\
\hline 26/01/2014 - 09:00 & 20 & 0.57 & 0 & 0 \\
\hline $26 / 01 / 2014-10: 00$ & 21 & 0.57 & 0 & 0 \\
\hline $26 / 01 / 2014-11: 00$ & 22 & 0.57 & 0 & 0 \\
\hline $26 / 01 / 2014-12: 00$ & 23 & 0.57 & 0 & 0 \\
\hline 26/01/2014 - 13:00 & 24 & 0.57 & 0 & 0 \\
\hline $26 / 01 / 2014-14: 00$ & 25 & 0.57 & 0 & 0 \\
\hline
\end{tabular}

Data input of the hydraulic calculation was river geometry in form of the cross-section that was resulted from measurement, followed with inline structure (Figure 11), and boundary condition as the requirement of unsteady flow simulation on HEC-RAS 4.1.0 software. The data were already saved in the software database, which then able to facilitate the users when running the software. Technical data of Colo Weir gate operational pattern which was used in this simulation are:

a) Gate operational operate two gate openings,

b) Using the overflow gate type (open air),

c) The gate is opened maximum at $5 \mathrm{~m}$ height.

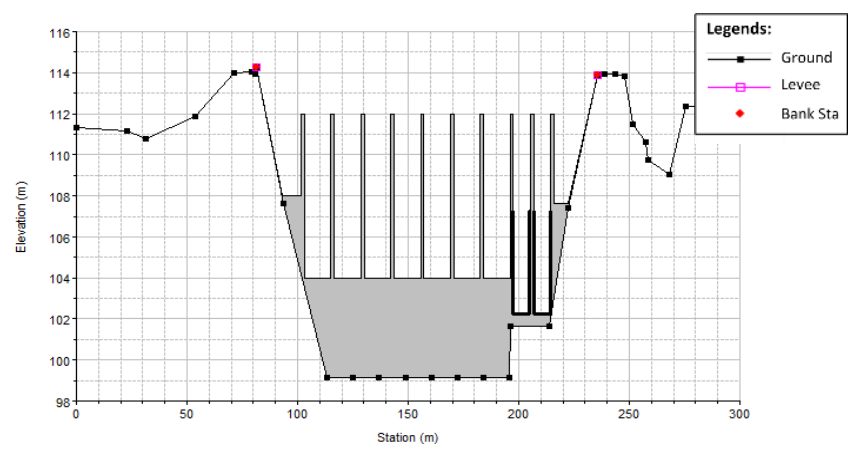

Figure 11. Inline structure of Colo Weir di RS. 746.10.
Next step was conducting the unsteady flow simulation. The time interval in simulation calculation was recommended at 2-minutes time interval for computation interval, 1 hour for hydrograph output interval and detailed output interval. The result of hydraulic flood routing simulation showed the flood characteristics at the control points, which are as follows.

\section{a) Colo Weir}

Maximum flood discharge of $157 \mathrm{~m}^{3} / \mathrm{s}$ was occurred on January 26th 2014 on 15:00, with volume of 26,020.31 $\mathrm{m}^{3}$. Maximum water level of $104.67 \mathrm{~m}$ was occurred at January 26th 2017 at 13:00.

\section{b) Jurug AWLR Station}

Maximum flood discharge of $249 \mathrm{~m}^{3} / \mathrm{s}$ was occurred on January $27^{\text {th }} 2014$ on 04:00, with volume of $39,014.31$ $\mathrm{m}^{3}$. Maximum water level of $80.70 \mathrm{~m}$ was occurred at January $26^{\text {th }} 2017$ at 18:00. The final result of this simulation was presented in Table 8 in which showed the information about the amount of inflow and outflow discharge of the reservoir, fluctuation of reservoir water level in both SSR and MR, spillway gate operation (Table 9), and also the flow condition in Colo 
Weir and Jurug AWLR Station. This simulation gave the information on the flood characteristic, in the form of flood discharge and maximum water level gauge on control points of Colo Weir and Jurug AWLR Station.

\subsection{Flood Performance}

\subsubsection{Flood Performance in Wonogiri Reservoir}

The reservoir flood routing simulation was conducted with entering hydrograph input of Wonogiri Reservoir inflow in return period of 60 years, 500 years, and PMF, which was a research result from Ansita Gupitakingkin (2014). Based on the design of Nippon Koei Co. Ltd, (2007), for the 60-years and 500-years return period floods, reservoir outflow operation use new spillway, whereas for PMF, the operation uses new and old spillways. The result of reservoir flood routing for 60-years return period is shown in Figure 12.

Based on Figure 12, the water level at SSR and MR are still below the closure dike peak elevation $(+139.4 \mathrm{~m})$. There was no runoff from SSR to MR and vice versa, because each elevation did not exceed the overflow dike elevation $(+137 \mathrm{~m})$. Based on the maximum water level, the reservoir condition is safe from the potency of overtopping, since it is still below the critical water level limit $(+139.1 \mathrm{~m})$. Further then, reservoir flood routing simulation was conducted for the 500-years return period flood (Figure 13).

Based on Figure 13, the maximum water level at SSR is $+138.77 \mathrm{~m}$, and at MR is +138.03 ; whereas both are still below the closure dike peak. On the 500-years return period flood simulation, full opening gate was conducted, started from the $7^{\text {th }}$ hour because the reservoir water level exceeded $+138.2 \mathrm{~m}$. This was conducted to avoid the overtopping on Wonogiri Reservoir.

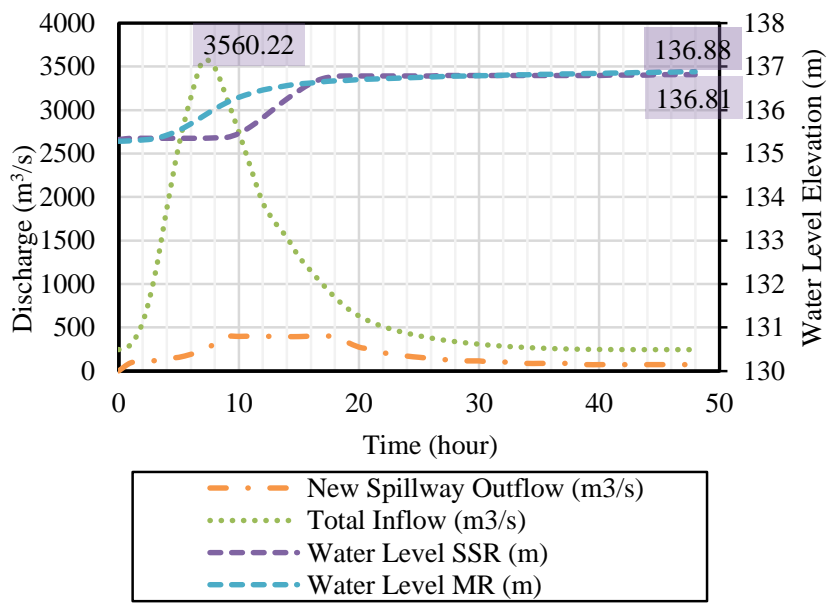

Figure 12. Reservoir flood routing for 60-years return period flood.

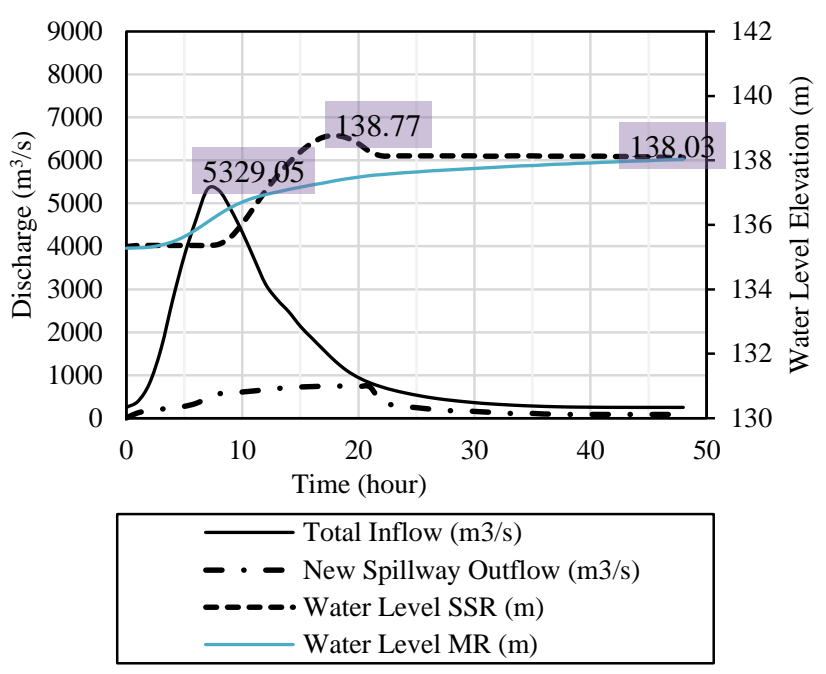

Figure 13. Reservoir flood routing for 500-years return period flood.

Further, reservoir flood routing simulation was conducted for the PMF (Figure 14). Reservoir flood routing simulation for PMF operated simultaneously on new and old spillways; and the outflow from the old spillway was $400 \mathrm{~m}^{3} / \mathrm{s}$. From the result of reservoir flood routing for PMF, it was known that the SSR maximum water level was $+139.92 \mathrm{~m}(52 \mathrm{~cm}$ above the closure dike), and for the MR was $+137.12 \mathrm{~m}$ (below the closure dike peak). This condition is compatible with the Nippon Koei (2007) design, in which at condition of PMF, the reservoir water level is allowed to overtopping through the closure dike.

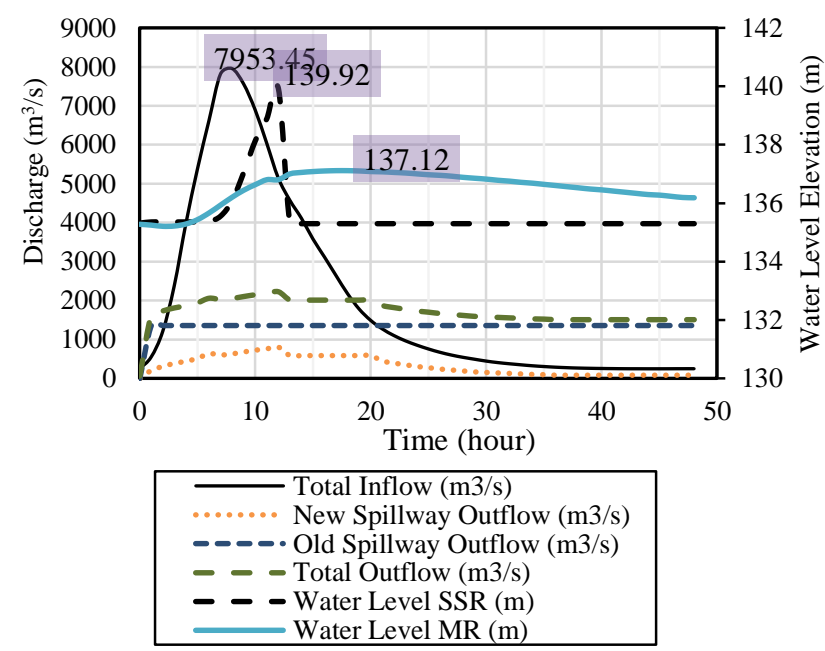

Figure 14. Reservoir flood routing for PMF.

Recapitulation of the results from reservoir flood routing on Nippon Koei design and on simulation result is presented in Table 10. It is known that by the presence of a closure dike, the maximum outflow discharge and the reservoir maximum water level were increased. The increase of maximum outflow discharge 
for 500 -years return period was $66.67 \%$ and $73.99 \%$ at PMF. The increase of outflow discharge also increases the risk on Wonogiri Reservoir downstream. On the other hand, there was also an increase in maximum water level, which are $0.01 \mathrm{~m}$ for 60 -years return period, $0.97 \mathrm{~m}$ for 500 -years return period, and $1.32 \mathrm{~m}$ for PMF.

\subsubsection{Flood Characteristic on Downstream of the Reservoir}

To obtain the flood characteristic that occurs on the downstream of reservoir, simulation based on certain rain event was conducted. As an example, simulation with real-time rainfall data input on January $25^{\text {th }} 2014$ was conducted. The result of the simulation was compared with the data from observation that was conducted by Perum Jasa Tirta I.

From the software simulation, it was seen that the maximum outflow discharge was of $80 \mathrm{~m}^{3} / \mathrm{s}$ until January $27^{\text {th }} 2017$ at $06: 00$; and next was of $79 \mathrm{~m}^{3} / \mathrm{s}$ until the end of simulation (see Figure 15). The difference between result from simulation and observation was that the outflow discharge that the old spillway released was of $100 \mathrm{~m}^{3} / \mathrm{s}$ until January $25^{\text {th }}$ 2014 at 09:00, and $140 \mathrm{~m}^{3} / \mathrm{s}$ for so forth.

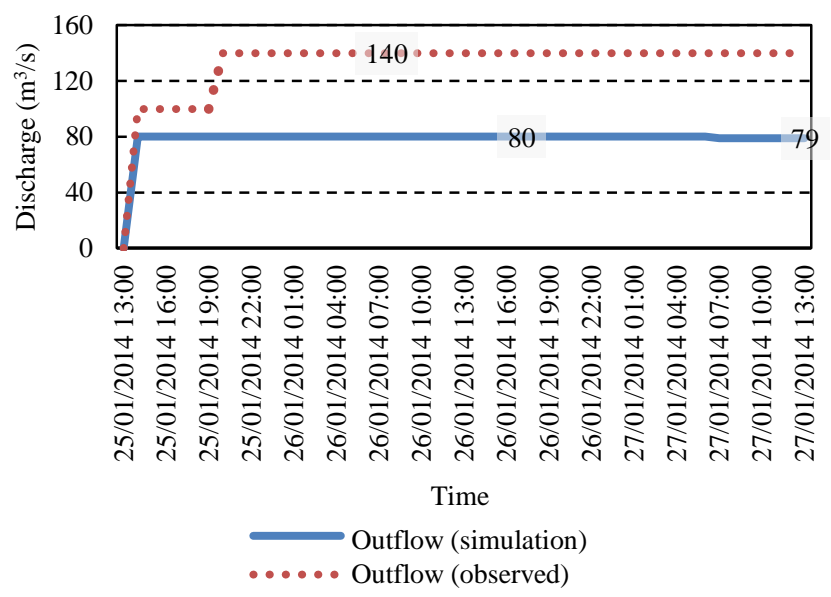

Figure 15. Reservoir outflow.
The flood characteristic on control points of Colo Weir and Jurug AWLR Station was obtained from the result of hydraulic flood routing simulation. The simulation result showed that the maximum water level in Colo Weir was $3.92 \mathrm{~m}$ lower than the result of field observation (Figure 16). The water level on Jurug AWLR Station showed the difference, in which the simulation result was $0.41 \mathrm{~m}$ lower (see Figure 17).

The water level fluctuation difference in simulation and field observation results was due to several possibilities. First is the difference in reservoir operational guideline, in which when the simulation used new reservoir operation, old guideline was used at flood in January $25^{\text {th }} 2014$ (was only operating old spillway). The second possibility was due to the decrease of the unit hydrograph, which still using synthetic unit hydrograph that caused the calculated lateral inflow discharge was still less accurate, also the input unsteady flow data only calculated 5 tributaries that give the biggest contribution to flood discharge in Upper Solo River Wonogiri Reservoir until the Jurug AWLR Station. The third possibility was the calibration of watershed parameter was only conducted on one flood event; therefore lead to the calibration of watershed parameters was not yet optimal.

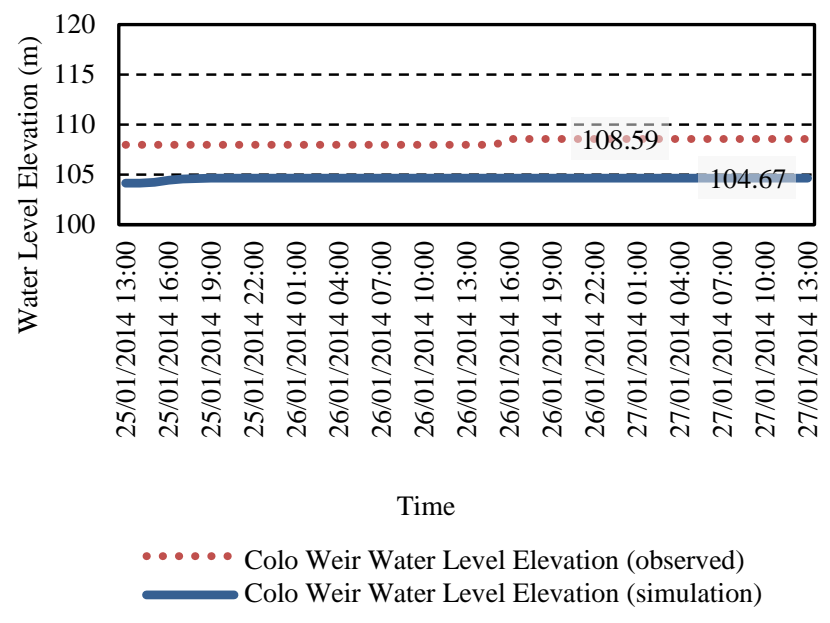

Figure 16. Water level elevation on Colo Weir.

Table 10. Recapitulation of comparison from reservoir flood routing results

\begin{tabular}{|c|c|c|c|c|c|c|c|c|c|}
\hline \multirow{3}{*}{$\begin{array}{l}\text { Return } \\
\text { Period } \\
\text { (year) }\end{array}$} & \multirow{3}{*}{$\begin{array}{l}\text { Maximum } \\
\text { Inflow } \\
\text { Discharge } \\
\left(\mathrm{m}^{3} / \mathrm{s}\right)\end{array}$} & \multicolumn{3}{|c|}{ Maximum Outflow Discharge $\left(\mathrm{m}^{3} / \mathrm{s}\right)$} & \multirow{3}{*}{$\begin{array}{l}\Delta \text { Maximum } \\
\text { Outflow } \\
\text { Discharge } \\
(\%)\end{array}$} & \multicolumn{3}{|c|}{$\begin{array}{l}\text { Maximum Water Level } \\
\text { Elevation }(\mathrm{m})\end{array}$} & \multirow{3}{*}{$\begin{array}{l}\Delta \text { Maximum } \\
\text { Water Level }(\mathrm{m})\end{array}$} \\
\hline & & \multirow{2}{*}{$\begin{array}{l}\text { Old } \\
\text { Condition }\end{array}$} & \multicolumn{2}{|c|}{ New Condition } & & \multirow{2}{*}{$\begin{array}{l}\text { Old } \\
\text { Condition }\end{array}$} & \multicolumn{2}{|c|}{ New Condition } & \\
\hline & & & $\begin{array}{l}\text { Old } \\
\text { Spillway }\end{array}$ & $\begin{array}{l}\text { New } \\
\text { Spillway }\end{array}$ & & & MR & SSR & \\
\hline 60 & $3,560.22$ & 415 & - & 405 & -2.41 & 136.80 & 136.88 & 136.81 & 0.01 \\
\hline 500 & $5,329.05$ & 447 & - & 745 & 66.67 & 137.80 & 138.03 & 138.77 & 0.97 \\
\hline PMF & $7,953.44$ & 1,242 & 1,360 & 801 & 73.99 & 138.60 & 137.12 & 139.92 & 1.32 \\
\hline
\end{tabular}




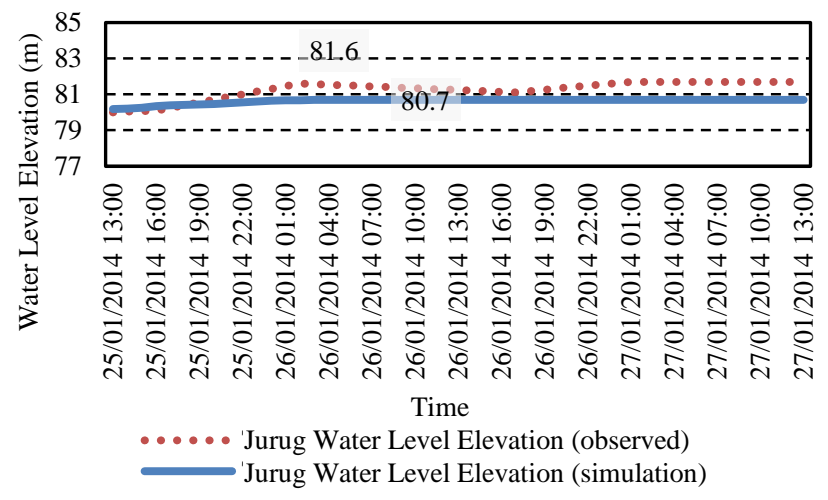

Figure 17. Water level elevation on Jurug AWLR station.

\section{CONCLUSIONS}

The simulation results can be summarized as follows:

a) There were significant changes on the simulation result of flood hydrograph Wonogiri Reservoir outflow when compared with the operating rule that the Nippon Koei Co. Ltd (2007) arranged, in the form of outflow discharge increase of $66.67 \%$ for 500-years return period and $73.99 \%$ for PMF. The water level elevation increased $0.97 \mathrm{~m}$ for 500-years return period and $1.32 \mathrm{~m}$ for PMF.

b) Characteristic of flood hydrograph of January $25^{\text {th }}$ 2014 flood event simulation result was that the water level elevation was lower than the observation result. This was because the flood routing simulation based on the new condition of the reservoir operation, whereas only the new spillway was being operated; while the outflow real operational data was only came from old spillway (still using the old operational guide).

\section{REFERENCES}

Amalia, A., 2014. Studi Pengaruh Pembangunan Closure Dike Waduk Wonogiri Terhadap Kondisi
Banjir di Hilir Waduk, Yogyakarta: Master Thesis Report. Universitas Gadjah Mada.

Amalia, B. A. R., 2014. Analisis Karakteristik Banjir Sungai Bengawan Solo Ruas Bendung Colo - Kota Surakarta, Yogyakarta: Undergraduate Thesis Report. Universitas Gadjah Mada.

Gunawan, 2009. Studi Banjir Bengawan Solo 2007 untuk Peningkatan Kinerja Mitigasi Bencana Banjir, Yogyakarta: Master Thesis Report. Universitas Gadjah Mada.

Gupitakingkin, A., 2014. Studi Pengaruh Pembangunan Closure Dike Waduk Wonogiri Terhadap Pola Operasi Waduk Periode Banjir. Tesis, Yogyakarta: Master Thesis Report. Universitas Gadjah Mada.

Hanova, Y., 2014. Pengembangan Perangkat Lunak Model Simulasi Hidrologi untuk Pengendalian Banjir Wilayah Sungai Bengawan Solo Hulu, Yogyakarta: Master Thesis Report. Universitas Gadjah Mada.

Nippon Koei Co. Ltd, 2007. The Study on Countermeasures for Sedimentation in Wonogiri Multipurpose Dam Reservoir in The Republic of Indonesia. Final Report, The Republic of Indonesia: Ministry of Public Works.

Oktavia, S. R., 2013. Pengembangan Model Hidrologi untuk Estimasi Hidrograf Inflow Waduk Wonogiri, Yogyakarta: Master Thesis Report. Universitas Gadjah Mada.

Wijaya, A. P., 2014. Pembuatan Perangkat Lunak Untuk Mendukung Pengendalian Banjir DAS Bengawan Solo Hulu, Yogyakarta: Master Thesis Report. Universitas Gadjah Mada. 